\title{
Sea Turtles in Florida's Atlantic Waters
}

\author{
CAITLIN M. BOVERY and JEANETTE WYNEKEN
}

\section{Introduction}

Knowledge of a species' spatial and temporal movement patterns is essential to management and conservation strategies, especially for highly mobile wildlife species. This is particularly true for marine species that occupy multiple habitats throughout their lifetime. Each habitat can present dramatically different abiotic and biotic challenges (Balon, 1986; Crawford and Balon, 1994; Wainwright and Richard, 1995). Ontogenetic habitat shifts are particularly common in marine organisms and are widespread among a variety of vertebrates (Price and Grant, 1984; Fishelson et al., 1987; Lind and Welsh, 1994; Kitowski, 2003; Page et al., 2005). Marine turtles undergo multiple ontogenetic habitat shifts (Bolten, 2003b; McClellan and Read, 2007; Snover, 2008) as they migrate across ocean basins and along coastal zones (Dodd and Byles,

The authors are with the Department of Biological Sciences, Florida Atlantic University, 777 Glades Road, Boca Raton, FL 33431 (corresponding author email: cbovery@fau.edu).

doi: dx.doi.org/10.7755/MFR.75.3.1
2003; Eckert et al., 2006; Foley et al., 2008; Girard et al., 2009). Various pelagic or benthic communities serve as temporary homes at different stages and within a single stage of their life cycle (Witzell, 2002; Bolten, 2003a; Polovina et al., 2006; Casale et al., 2008; Witherington et al., 2012). Documentation of where and when marine turtles move among habitats is scattered across both reviewed and gray literature. Consequently, such habitat shifts are poorly understood.

Although some species, such as the loggerhead, Caretta caretta, and green, Chelonia mydas, turtles may vary among populations and individuals in the details of their life history patterns (Hatase et al., 2006; McClellan and Read, 2007; Mansfield et al., 2009), all sea turtles begin life as terrestrial hatchlings. Hatchlings crawl to the sea, immediately transitioning to life in the marine environment as they swim offshore (Carr and Ogren, 1960). Some hatchlings and posthatchling turtles then associate with flotsam, such as Sargassum communities and downwelling lines (Carr and Meylan, 1980; Witham, 1980; Carr,

ABSTRACT-Management of marine turtles presents various challenges due to their highly migratory nature, which includes major ontogenetic habitat shifts, seasonal movements between feeding grounds, and migrations to and from breeding grounds. Further, sea turtle spatial distributions often differ in species-specific ways during similar temporal periods. Various approaches combine to give valuable insights into spatial and temporal distributions of sea turtles and provide critical knowledge for understanding and protecting these imperiled species. Here we summarize and synthesize available data that document sea turtle occurrences in waters from the Florida Straits (lat. $24^{\circ} 28^{\prime} \mathrm{N}$ ) north to the latitude of Jacksonville, Fla. (lat. $30^{\circ} 20^{\prime} \mathrm{N}$ ), including waters up to $150 \mathrm{~km}$ offshore, termed Florida's Atlantic waters for this review. We summarize 951 satellite tracked sea turtles, 288 of which crossed into Florida's Atlantic waters. All species of sea turtles inhabiting the Atlantic Ocean were found to use Florida Atlantic waters. Sea turtles use Florida's Atlantic waters year-round, yet distributions of individual species vary seasonally. We provide a current synthesis describing the sea turtles species using Florida's Atlantic waters and suggest areas where further study may be warranted. spatial and temporal distributions of the five
1986; Coston-Clements et al., 1991; Witherington, 2002) in oceanic waters. They may remain in oceanic habitats for several years (Carr et al., 1966; Carr, 1987; Collard and Ogren, 1990; Musick and Limpus, 1997; Bjorndal et al., 2000b, 2003; Reich et al., 2007a).

After a variable amount of time in the epipelagic zone, many of these turtles return as juveniles and sub-adults (large juveniles) to nearshore waters and inhabit the neritic zone (Bjorndal et al., 2003), while others alternate between oceanic and neritic foraging grounds (Bolten, 2003a; McClellan and Read, 2007; Mansfield et al., 2009). Such habitat shifts reflect dietary shifts. However, the direction of the cause-effect relationship remains a point of discussion (Witzell, 2002; McClellan and Read, 2007; Casale et al., 2008).

As sea turtles approach maturity, they move to waters in closer proximity to nesting beaches (Bowen et al., 2005) and commence migratory breeding cycles every one to nine years depending on the species and ocean basin (Carr and Ogren, 1960; Miller, 1997). During nesting season, adult turtles temporarily reside in neritic waters along the continental shelf, just off nesting beaches (Stoneburner, 1982; Mortimer and Porter, 1989; TEWG, 2009). After depositing their last clutch of the season, adult females may migrate thousands of kilometers to foraging areas (Caldwell et al., 1959; Bell and Richardson, 1978; Meylan et al., 1983; Girard et al., 2009; Plotkin and Spotila, 2002).

All species of sea turtles in the western Atlantic Ocean occur in Florida's Atlantic waters (Caldwell and Carr, 1957), including loggerhead; green; leatherback, Dermochelys coria- 
cea; hawksbill, Eretmochelys imbricata; and Kemp's ridley, Lepidochelys kempii, turtles. Moreover, peninsular Florida supports one of the largest loggerhead rookeries in the world with an average of 65,460 nests from 1989 to 2006 (TEWG, 2009), constituting the majority $(80 \%)$ of loggerhead nesting in the western Atlantic Ocean (Dodd, 1988; Ehrhart et al., 2003; TEWG, 2009). Florida's east coast beaches also support growing rookeries for green turtles (Witherington et al., 2006) and leatherbacks (TEWG, 2007; Stewart et al., 2011). Consequently, waters adjacent to Florida's east coast include increasing numbers of turtles during reproductive periods.

We summarize here available information describing sea turtle locations/ distributions in Florida's Atlantic waters. We completed a thorough review of available literature in the field and compiled a comprehensive assessment of sea turtles satellite tracked through these waters. With these assessments, we identified areas lacking data and suggest future directions for study of sea turtles in Florida's Atlantic waters.

\section{Methods}

\section{Literature Identification and Review}

We draw data from several major methodologies to summarize our understanding of sea turtle distributions and movements throughout Florida's Atlantic waters (Fig. 1). Information about sea turtle distributions throughout Florida's coastal waters comes from in-water studies employing a wide range of methodologies, including direct capture (Henwood, 1987; Bresette et al., 1998;

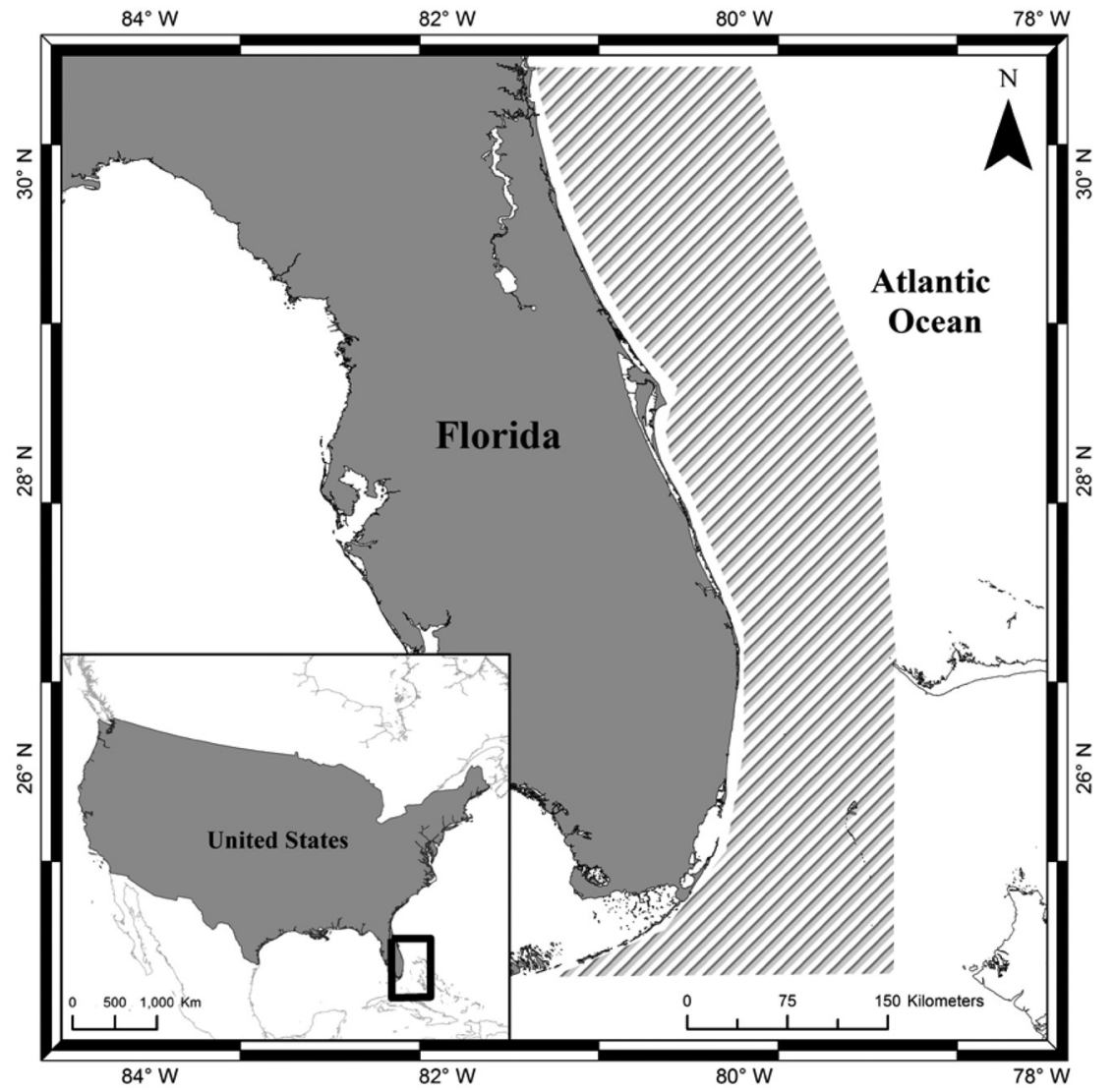

Figure 1.-Atlantic coast of Florida. Gray hatched area indicates the Florida's Atlantic waters included in this review, from the Florida Straits north to Jacksonville, Fla., including waters up to $150 \mathrm{~km}$ offshore.
Ehrhart et al., 2007; Hawkes et al., 2007, 2011; Arendt et al., 2012a,b,c), satellite telemetry (Blumenthal et al., 2006; Girard et al., 2009; Mansfield et al., 2009; Arendt et al., 2012a,b,c; Ceriani et al., 2012), shipboard surveys (Bresette et al., 2010), aerial surveys (Fritts et al., 1983; Schroeder and Thompson, 1987; Epperly et al., 1995, 2002; McClellan, 1996; Witzell and Azarovitz, 1996; Henwood and Epperly, 1999; Goodman et al., 2007), stable isotopes (Reich et al., 2007a, b; Ceriani et al., 2012), and bycatch records (Thompson et al., 1991; Epperly et al., 2002). Mark-recapture via flipper or pit tagging provides start and end point data demarking some travels (Meylan, 1995; Schmid and Witzell, 1997; Witzell, 1998; Williams and Frick, 2008). The results of these and other studies indicate a widespread distribution of marine turtles in Florida's Atlantic waters.

Literature for this review was compiled using the following databases: Sea Turtle Online Bibliography (st.cits. fcla.edu/st.jsp), seaturtle.org document library (www.seaturtle.org/tracking), NOAA Southeast Fisheries Science Center Sea Turtle Publications (www. sefsc.noaa.gov/species/turtles/publications.htm), and Google Scholar. Search terms used to identify relevant literature included the scientific and common name of each turtle species found in Florida and combinations of the following: sea turtle, marine turtle, turtle, seaturtle, tracking, migration, swimming, distribution, satellite tracking, radio tracking, acoustic tracking, telemetry, tracking, Southern Gulf Stream, and Florida Current.

From the literature identified, publications were reviewed to determine if the turtles studied were present in Florida's Atlantic waters. Both gray and white literature was examined during the review process. Literature was excluded if positions of tracked turtles were not rigorously filtered or if interpretations extended beyond the scope of the data collected. Additionally, geographic constraints were applied limiting the literature incorporated to studies in which turtles were found in 
the southern extent of the Gulf Stream, the Florida Current, nearshore waters along the southeast coast of Florida, or waters abutting the western Bahamas Banks. The study area that we used for the geographic limitation extended from lat. $30^{\circ} 20^{\prime} \mathrm{N}$ south to lat. $24^{\circ} 28^{\prime} \mathrm{N}$ and out to $150 \mathrm{~km}$ from the Florida coastline (Fig. 1). Where turtle locations were not tracks or direct sightings, for example mark-recapture (tag returns), we included only turtles whose locations could be interpolated in a realistic time frame. We cross-referenced publications to prevent the use of double-reported data.

\section{Spatial Distribution Summarization}

To complement our literature review, we compiled a summary of all available satellite telemetry studies that occurred within the spatial confines of our review. Archived and active sea turtle tracking programs of study hosted by seaturtle.org and conserveturtles.org were surveyed for turtles tracked through Florida's Atlantic waters. Visual and qualitative screening excluded erroneous sea turtle tracks. Once relevant tracks were identified, data owners were contacted to request permission to include sea turtle tracks in species-specific tabulations. We did not request permission to include track details. The unpublished studies were tabulated with relevant satellite tracking literature results to establish tallies of all available data documenting turtle species, as well as when and where they are present, throughout Florida's Atlantic waters.

\section{Summary Metrics}

When we identified turtles which used our study area, we tallied the (1) total number of sea turtles tracked by those various research programs, (2) number tracked through Florida's Atlantic waters, and (3) calculated percentages of tracked turtles that used Florida's Atlantic waters. Additionally, we acquired maps representing aerial and vessel survey sightings of loggerhead turtles to illustrate the spatial distribution of the most common species found in Florida's Atlantic waters. Results were summarized and analyzed to identify data gaps in the understanding of sea turtles in Florida's Atlantic waters.

\section{Results}

Thirty-three sources of sea turtle satellite tracking data were identified for use in this study. A total of 951 sea turtles were tracked using satellite telemetry, including 578 loggerhead, 109 leatherback, 92 green, 159 Kemp's Ridley, and 13 hawksbill tur-

Table 1.-Summary of sea turtle satellite tracking programs that observed turtles within Florida's Atlantic waters.

\begin{tabular}{|c|c|c|c|c|c|c|c|c|c|c|}
\hline \multirow[b]{2}{*}{ Species } & \multicolumn{3}{|c|}{ Total no. tracked } & \multicolumn{3}{|c|}{$\begin{array}{l}\text { No. tracked in } \\
\text { Florida's Atlantic waters }\end{array}$} & \multicolumn{3}{|c|}{$\begin{array}{l}\text { Percentage tracked in } \\
\text { Florida's Atlantic waters }\end{array}$} & \multirow[b]{2}{*}{ Citations } \\
\hline & Adult & Sub-adult & Juvenile & Adult & Sub-adult & Juvenile & Adult & Sub-adult & Juvenile & \\
\hline Loggerhead & 337 & 93 & 148 & 105 & 59 & 19 & $31.2 \%$ & $63.4 \%$ & $12.8 \%$ & $\begin{array}{c}1,2,4,6,7,8,9,10,12,13, \\
16,17,21,22,23,24,25,28,31\end{array}$ \\
\hline Leatherback & 109 & 0 & 0 & 48 & 0 & 0 & $44.0 \%$ & $-^{*}$ & $-^{*}$ & $3,11,13,14,26$ \\
\hline Green & 31 & 44 & 17 & 3 & 31 & 9 & $9.7 \%$ & $70.5 \%$ & $52.9 \%$ & $3,5,12,15,18,22,23,24,27$ \\
\hline Kemp's Ridley & 4 & 55 & 100 & 1 & 2 & 6 & $25.0 \%$ & $3.6 \%$ & $6.0 \%$ & $18,19,20,21,23,24,25,29,30$ \\
\hline Hawksbill & 5 & 8 & 0 & 0 & 5 & 0 & $0.0 \%$ & $62.5 \%$ & $-^{*}$ & $12,27,32$ \\
\hline Totals & 486 & 200 & 265 & 157 & 97 & 34 & $32.3 \%$ & $48.5 \%$ & $12.8 \%$ & \\
\hline
\end{tabular}

*No turtles of this size class were tracked using satellite telemetry in Florida's Atlantic waters.

Arendt et al., 2012b.

${ }^{2}$ Arendt et al., 2012c.

${ }^{3}$ Bagley, D. A., Research Associate, University of Central Florida, Orlando, Fla. Personal commun., 2013.

${ }^{4}$ Dodd and Byles, 2003.

${ }^{5}$ Shaver, D. J., Chief, Division of Sea Turtle Science and Recovery, National Park Service, Padre Island National Seashore, Corpus Christi, Tex. Personal commun., 2012.

${ }^{5}$ Shaver, D. J., Chief,
${ }^{6}$ Foley et al., 2008.

${ }^{7}$ Girard et al., 2009.

${ }^{8}$ Gumbo Limbo Nature Center, Boca Raton, Fla.

${ }^{9}$ Hawkes et al., 2007.

${ }_{11}^{10}$ Hawkes et al., 2011.

${ }^{12}$ Hart, K. M., Research Ecologist, U.S. Geological Survey, Southeast Ecological Science Center, Davie, Fla. Personal commun., 2013.

${ }_{13}$ Lart, K. M., Research Ecologist, U.S. Geological Survey, Southeast Ecological
Loggerhead Marinelife Center, Juno Beach, Fla., 2002-2011, unpubl. data.

${ }^{14}$ Eckert et al., 2006.

${ }^{15}$ Makowski et al., 2006

${ }_{16}$ McClellan and Read, 2007

${ }^{17}$ Phillips, 2011.

${ }^{18}$ Read, A., B. Foster, C. McClellan, and D. Waples. 2004. Habitat use of sea turtles in relation to fisheries interactions. Final Rep. N.C. Sea Grant Fish. Resour. Grant Prog., 02-

FEG-05, Raleigh, N.C., 121 p. (unpubl.).

${ }^{19}$ Renaud and Williams, 2005.

${ }^{20}$ Renaud, 1995.

${ }^{21}$ Sasso, C. R. Research fisheries biologist, NMFS SEFSC, Miami, Fla. Personal commun., 2013.

${ }^{22}$ The Georgia Sea Turtle Center, Jekyll Island, Ga.

${ }^{23}$ Tucker 2012. www.mote.org/seaturtles.

${ }^{24}$ Virginia Aquarium and Marine Science Center, Virginia Beach, Va.

${ }^{25}$ Godfrey, M. H. Biologist, N.C. Wildl. Resour. Comm., Beaufort, N.C. Personal commun., 2013.

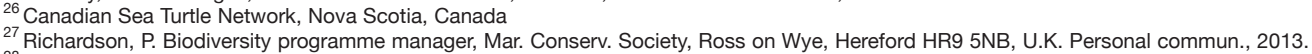

${ }^{28}$ Reriani et al., 2012

${ }_{30}^{29}$ Keinath, 1993

${ }^{30}$ Mansfield, 2006

${ }^{31}$ Mansfield, 2009

${ }^{32}$ Wood, L. Biologist, Palm Beach Zoo, West Palm Beach, Fla. Personal commun., 2013. 
tles (Table 1). Of those turtles tracked by data contributors, a total of 299 sea turtles were observed in Florida's Atlantic waters in the duration of their track, including 183 loggerhead, 48 leatherback, 43 green, 9 Kemp's ridley, and 5 hawksbill turtles (Table 1). Percentage of the sea turtles tracked that crossed into Florida's Atlantic waters is summarized in Table 1. The seasonal changes in loggerhead movements are illustrated in Figure 2 to supplement the satellite tracking information and review of loggerhead presence in Florida's Atlantic waters.

The literature review identified a variety of habitats along Florida's Atlantic coast that host sea turtles. Drifting Sargassum communities support early stages of loggerhead, green, hawksbill, and Kemp's ridley sea turtles. Neritic zones of Florida's Atlantic waters provide habitat for a variety of life stages of loggerhead, green, hawksbill, and Kemp's ridley sea turtles that rely on nearshore reefs, coastal lagoons, and shorelines for developmental, breeding, and nesting grounds. Neritic waters also serve as access to nesting beaches for loggerhead, green, leatherback, hawksbill, and occasionally Kemp's ridley turtles. Additionally, pelagic zones of Florida's Atlantic waters are used by loggerhead, green, hawksbill, Kemp's ridley, and leatherback turtles as migratory pathways.

\section{Discussion}

All five species of sea turtles use Florida's Atlantic waters. There are species-specific differences in the relative abundances associated with seasons and with movements to and from rookeries. Here we discuss each species' use of Florida's Atlantic waters and highlight the trends in size class occurrence relative to the $200 \mathrm{~m}$ isobath. We end with a discussion of the satellite track data.

\section{Loggerhead Turtles}

U.S. beaches along peninsular Florida, as well as Florida's Atlantic waters adjacent to the coastline, provide essential habitat for one of the world's largest loggerhead sea turtle rooker- ies. A significant portion of the world's population of loggerhead turtles, up to $80 \%$ of the North Atlantic population, nests on peninsular Florida's beaches and produce $\sim 90 \%$ of all hatchlings in the western North Atlantic Ocean (TEWG, 2009). Hatchling and small juvenile loggerhead turtles (mean \pm standard deviation $=46.9 \pm 3.2 \mathrm{~mm}$ straight carapace length (SCL), range $=40.9-78.4 \mathrm{~mm}$ ) from Florida's east coast beaches have been observed in Sargassum lines and frontal zones along the east coast of Florida (Witherington, 2002; Witherington et al., 2012) and so transit Florida's Atlantic waters. Direct observations show that these turtles then move to forage and grow in oceanic waters in the eastern North Atlantic (Bolten et al., 1998; Monzón-Argüello et al., 2009).

After an estimated 6.5-11.5 years as oceanic juveniles, loggerheads (SCL $=46-64 \mathrm{~cm}$ ) return to developmental habitats within neritic waters, including Florida's east coast (Bjorndal et al., 2000b, Bolten, 2003b; Snover et al., 2010). These waters provide important developmental habitats for juvenile loggerheads originating from Florida, Mexico, the U.S. eastern seaboard, and other Atlantic nesting beaches (Witzell et al., 2002). Additionally, waters along the east coast of Florida provide seasonal overwintering habitats and year-round foraging grounds for loggerhead turtles (Henwood, 1987; Keinath, 1993; Ehrhart et al., 2007; McClellan and Read, 2007; TEWG, 2009; Arendt et al., 2012b).

Some juvenile loggerheads along Florida's east coast undergo seasonal migrations northward in warmer months and migrate south when water temperatures decline in the fall (Lutcavage and Musick, 1985; Carr, 1987; Musick and Limpus, 1997; TEWG, 2009). Mansfield et al. (2009) documented seasonal movements of juvenile loggerheads from the Chesapeake Bay to areas off of North Carolina, with two turtles moving as far south as Florida's east coast. Large juvenile loggerheads $(\bar{x}=62.6 \pm 4.9 \mathrm{~cm}$ SCL, range $=57.5-75.8 \mathrm{~cm}$ ) caught in North Carolina were also tracked into
Florida's Atlantic waters (McClellan and Reed, 2007).

Juvenile loggerheads as small as 45 $\mathrm{cm}$ SCL are captured in coastal waters between St. Augustine, Fla. (lat. $29^{\circ} 53^{\prime} \mathrm{N}$ ), and Brunswick, Ga. (lat. $31^{\circ} 09^{\prime} \mathrm{N}$ ), during the spring and summer months (Arendt et al., 2012c; Table 1) and near Cape Canaveral (lat. $28^{\circ} 23^{\prime} \mathrm{N}$ ) during winter months (Ogren and McVea, 1995). Juvenile loggerheads have been captured throughout the Indian River Lagoon (Ehrhart et al., 2007), indicating their arrival from oceanic habitats, although their routes to the coastal lagoons are poorly documented. Juvenile and adult loggerheads also use coastal bays and inlets as feeding and wintering habitats. For example, loggerhead turtles captured $(\bar{x}=80.1 \mathrm{~cm}$ SCL, range $=$ $48.9-98.7 \mathrm{~cm}$ ) year round within Florida Bay in the Florida Keys range from juvenile to near mature size classes (Schroeder et al., 1998).

The Port Canaveral Shipping Channel is an important area for adult loggerhead turtles (Carr et al., 1980). Results from five trawling studies in this area documented the capture of 3,132 individuals, $83 \%$ of which were juveniles (mean total carapace length $=69 \mathrm{~cm}, n=2,546)$ while $17 \%$ were adults (mean total carapace length $=$ $92 \mathrm{~cm}, n=586$ ) (Henwood, 1987). Of the adults captured, 271 were female and 315 were males. Adult males were captured primarily during March through May, while adult females were mostly captured from April through August (Henwood, 1987). Henwood (1987) suggested that these adults display short-term residency in this area before moving to other foraging habitats after the nesting season ends. Moreover, Henwood (1987) noted that adult male migrations differed from those of adult females in that males entered the area prior to the arrival of females, with peak densities from April to May.

Juvenile loggerhead turtles are present year-round in the Port Canaveral Shipping Channel with greater abundances in the winter, suggesting a northward migration during spring and 

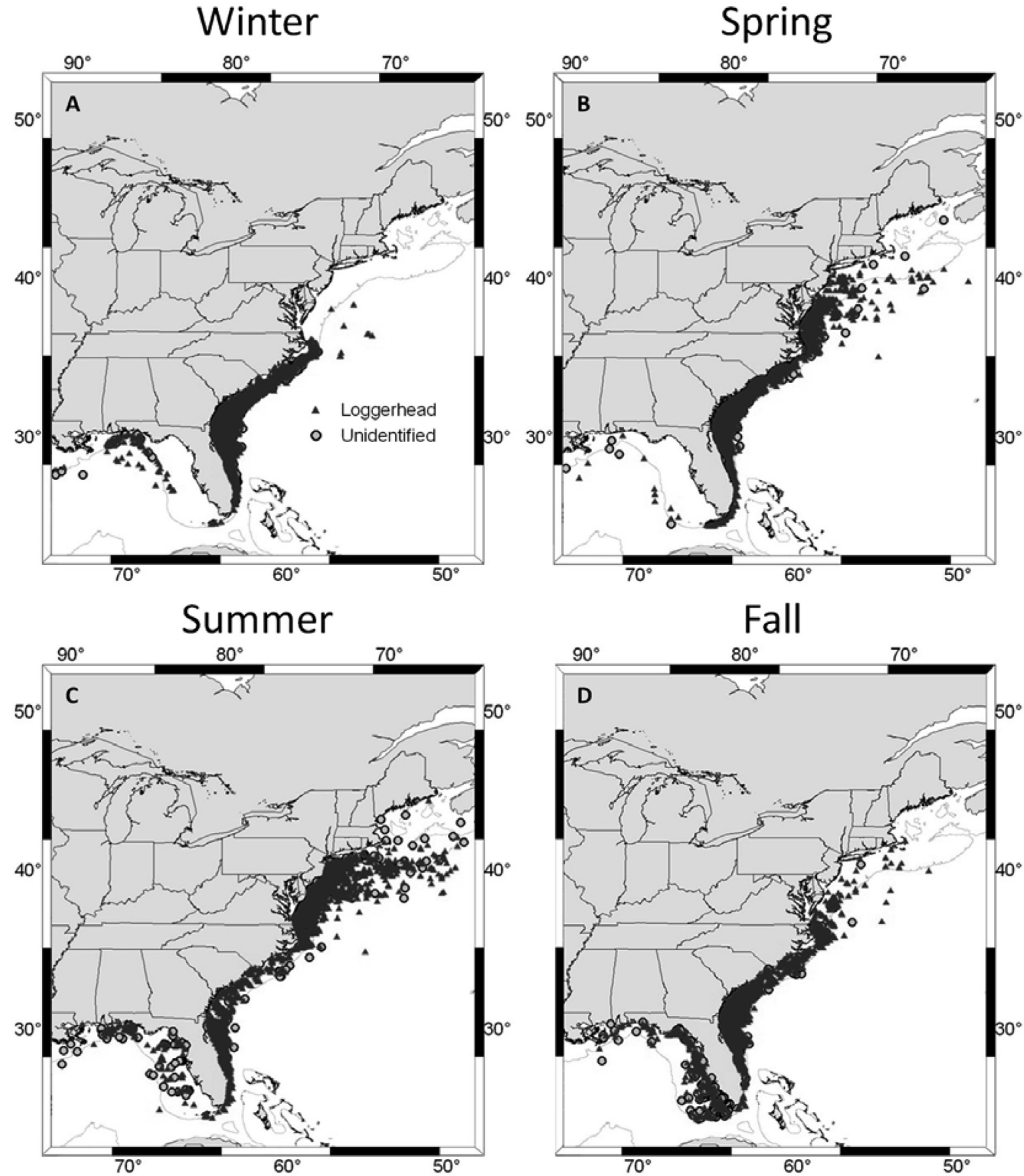

Figure 2.- Seasonal composites of loggerhead turtle, Caretta caretta, distributions from aerial and shipboard surveys conducted from the late 1970's to 2002: A) Winter (January-March), B) Spring (April-June), C) Summer (July-September), D) Fall (October-December). Reproduced with permission from Turtle Expert Working Group (2009). 
summer that coincides with warmer temperatures in higher latitudes (Henwood, 1987; Schmid, 1995). During trawling surveys conducted in 2006 and 2007 adjacent to Cape Canaveral, 158 loggerheads were captured, including 42 adult males, 9 adult females, and 107 juveniles; the smaller loggerheads were captured closer to shore (Arendt et al. ${ }^{1}$ ).

Mark-recapture studies indicate that post-nesting loggerhead females from the central east coast of Florida disperse to areas along the U.S. Atlantic Coast, Gulf of Mexico, and Caribbean (Meylan et al., 1983). Tracking studies have identified diverse routes between nesting, feeding, and overwintering grounds. Some loggerhead turtles tracked by satellite telemetry (Table 1) use Florida's Atlantic waters for varying amounts of time; others cross the Florida Current and move into Bahamian or Cuban waters, while others move north along Florida's east coast and the edges of the Gulf Stream (Caldwell et al., 1959; Meylan, 1995; Foley et al., 2008; Godley et al., 2008; Girard et al., 2009; Mansfield et al., 2009). Occasionally, post-nesting loggerhead turtles migrate from Florida's Atlantic waters to outer continental waters off of southwest Florida and into the Gulf of Mexico (Foley et al., 2008; TEWG, 2009).

Florida's Atlantic waters are important migratory pathways for turtles tagged elsewhere (TEWG, 2009), including those found nesting along North Carolina beaches (Hawkes et al., 2007) and in southwest Florida (Girard et al., 2009). Some post-nesting loggerheads travel along coastal routes, while others cross deep oceanic waters (Foley et al., 2008). Adult female loggerheads use waters near nesting beaches $(<50 \mathrm{~km})$ as well as areas distant from nesting beaches $(>700$ km, Foley et al., 2008). Post-nesting

\footnotetext{
${ }^{1}$ Arendt, M., J. Byrd, A. Segars, P. Maier, J. Schwenter, D. Burgess, J. Boynton, D. Whitaker, L. Liguori, L. Parker, D. Owens, and G. Blanvillain. 2009. Unpubl. Examination of local movement and migratory behavior during spring and summer along the Atlantic coast off the southeastern United States. Final report. Natl. Mar. Fish. Serv., 177 p. (avail. at http://www.sefsc. noaa.gov/turtledocs/CR_Arendt_etal_2009.pdf).
}

loggerheads tracked from the southwest coast of Florida show both localized and long-distance movements (Girard et al., 2009). Upon reaching overwintering habitats, females reside in well-defined, relatively small areas on the continental shelf off Florida, Texas, Mexico, and Bahamas (TEWG, 2009).

In the winter and spring, adult loggerheads are found north of Florida's central east coast, and in southern Floridian and Cuban waters (Fig. 2A, B; TEWG, 2009). In summer and fall, adult loggerhead turtles are more widely spread throughout coastal waters west of the $200 \mathrm{~m}$ isobath (Fig. 2C, D; TEWG, 2009).

Additional tracking studies indicate that adult male loggerheads utilize continental shelf waters throughout most of Florida (Arendt et al., 2012a, c). In spring (April-June), adult males are more evenly distributed throughout all continental shelf waters. In the summer (July-September), adult males aggregate along the west and east central coast of Florida, similar to fall (October-December). Resident males remained in the Port Canaveral area, moving further offshore after breeding, while migrant turtles dispersed to foraging grounds north and south of Port Canaveral (Arendt et al., 2012a, c).

Aerial surveys have increased our knowledge of the distribution and abundance of some marine turtles. Generally, larger individuals are more easily identified to species and more information on the at-sea distribution and abundance of these turtles is available (Epperly et al., 2002). Loggerhead sea turtles are often the most commonly observed species during aerial surveys (Hoffman and Fritts, 1982; Fritts, 1983; Thompson ${ }^{2}$ ) and have been observed throughout Florida's Atlantic waters (Fig. 2A-D; McClellan, 1996; TEWG, 2009). Aerial

${ }^{2}$ Thompson, T. J., and C. R. Shoop. 1983. Southeast Turtle Surveys (SETS), Pelagic surveys. Final report. Natl. Mar. Fish. Serv., Miami, Fla. NA82-GA-C-00012. Aero-Marine Surveys, Inc., Groton, Conn., 76 p. (avail. at http://www. sefsc.noaa.gov/turtledocs/CR_Shoop_Thompson_1983.pdf) surveys indicate that loggerheads are distributed along the entire southeast coast of Florida with greater abundances in the spring and summer (McClellan, 1996), coinciding with nesting season.

Aerial surveys conducted from the late 1970 's to 2002 found that the majority of turtle sightings occurred along the continental shelf out to the $200 \mathrm{~m}$ isobath (Fig. 2A-D; TEWG, 2009). In the summer, loggerheads utilize coastal waters east to the edge of the continental shelf with few turtles extending into deep waters of the shelf (Witzell and Azarovitz, 1996). In general, sea turtles primarily use midshelf waters during fall and winter and they are more uniformly distributed over the continental shelf in the spring and summer (Schroeder and Thompson, 1987), with the majority of loggerhead sightings occurring in waters $<100 \mathrm{~m}$, west of the Florida Current (Hoffman and Fritts, 1982; Schroeder and Thompson, 1987).

\section{Leatherback Turtles}

The leatherback turtle is the widest ranging reptile in the world, found in the Pacific, Atlantic, and Indian Oceans (Mrosovsky, 1987). Leatherbacks have been observed throughout Florida's nearshore and offshore waters (Stewart and Johnson, 2006). In contrast to other marine turtle species, leatherbacks are primarily pelagic (Musick and Limpus, 1997). Most of what is known about leatherbacks in Florida's Atlantic waters is derived from adult turtles.

Leatherback turtles nesting in Florida are considered a separate stock from the six other stocks in the Atlantic Ocean (TEWG, 2007). Peak leatherback nesting in Florida occurs along the Atlantic coast (Stewart et al., 2011). Leatherback nesting in Florida has increased by $10.2 \%$ since 1979 (Stewart et al., 2011). Few inwater observations of juvenile or adult leatherbacks have been documented in Florida waters (Bresette et al., 1998; Eckert, 2002), though records of nesting (Stewart et al., 2011) and worldwide juvenile sightings $(<145 \mathrm{~cm}$; 
Eckert, 2002) indicate that leatherbacks may utilize these waters. Musick and Limpus (1997) noted that the fate of leatherback hatchlings after they leave nesting beaches is unknown and little is known about pelagic juveniles. Eckert (2002) concluded that juvenile leatherback turtles reside primarily in warmer waters, transitioning to colder waters as they grow. Nevertheless, leatherbacks nest on Florida's east coast beaches and their hatchlings use Florida's Atlantic waters.

Leatherbacks primarily inhabit pelagic waters, make annual north-south migrations in the North Atlantic (Eckert, 1998; James et al., 2005; Eckert et al., 2006), and can swim over 10,000 $\mathrm{km} / \mathrm{yr}$ often across entire ocean basins (Eckert, 1998; Hughes et al., 1998; Eckert et al., 2006). Post-nesting adult females were tracked from Florida's Atlantic beaches for durations of 38 to over 454 days (Eckert et al., 2006). During the internesting period, these turtles moved north, occasionally remaining in waters over the continental shelf before returning to nest. Eckert et al. (2006) determined that the home-range of these animals was primarily along the continental shelf extending out to Gulf Stream waters east-southeast of Cape Canaveral and just off their nesting beaches. Adult female, adult male, and juvenile leatherback turtles tagged in waters off Nova Scotia, Canada, exhibited widely varied migration patterns throughout the western Atlantic Ocean (James et al., 2005). Individuals migrated to waters off nesting beaches as far south as the northeast coast of South America, Antilles, Panama, and Costa Rica, as well as continental shelf waters off the coast of the southeastern United States (James et al., 2005).

Data from aerial surveys and bycatch information provide much of our understanding of the distribution and abundance of leatherback turtles in waters bordering the entire southeastern United States. Their density is greatest along the east coast of central Florida where they primarily use mid-shelf waters throughout the year (Schroeder and Thompson, 1987; Ep- perly et al., 2002; TEWG, 2007). Here, most sightings of leatherbacks occur in summer, east of the $20 \mathrm{~m}$ isobath (Schroeder and Thompson, 1987). In addition, bycatch rates in the commercial shrimp industry are greatest in nearshore waters where fishing effort is concentrated (Epperly et al., 2002). Incidental capture of leatherback turtles in long-line fisheries suggest that relatively large numbers of leatherback turtles inhabit deep waters extending beyond the edge of the continental shelf, outside the $200 \mathrm{~m}$ isobath, especially during summer and fall months (Witzell and Cramer, 1995; Witzell, 1999). In general, aerial sightings indicate that leatherbacks are more abundant off the U.S. Atlantic coast during the summer than during the winter and sighted less frequently in nearshore waters (TEWG, 2007).

Fritts et al. (1983) reported sightings of leatherback turtles off the central east coast of Florida in spring and summer in mostly shallow continental shelf waters $<72 \mathrm{~km}$ from shore. Seasonal aerial surveys conducted from 1982 to 1984 observed leatherbacks during all seasons, with numbers peaking in summer months (Schroeder and Thompson, 1987). Hoffman and Fritts (1982) and Schroeder and Thompson (1987) found that leatherbacks were more abundant in the summer along Florida's central east coast and were concentrated at depths between 20 and $40 \mathrm{~m}$.

\section{Green Turtles}

Florida's Atlantic waters are important feeding grounds and migratory pathways for green turtles. Atlantic green turtles nest throughout Florida with peak nesting occurring along the east coast from approximately lat. $29^{\circ} 25^{\prime} \mathrm{N}$ to lat. $27^{\circ} 50^{\prime} \mathrm{N}$ (NMFS and USFWS, 2007). Annual nesting in Florida has steadily increased over the past several decades (Meylan et al., 2006; Witherington et al., 2006). Hatchlings depart the nesting beaches and are dispersed by ocean currents as they begin the oceanic phase of their life cycle (Carr and Meylan, 1980; Witham, 1980; Meylan et al., 2006).
During their oceanic phase, posthatchling turtles often associate with Sargassum and other flotsam accumulated along convergence zones caused by downwelling (Carr, 1987; Witherington et al., 2006; Witherington et al., 2012). In the Caribbean, Carr and Meylan (1980) documented neonate green turtles in Sargassum off the coast of Costa Rica. Large numbers of post-hatchlings commonly strand along Florida's central and northern east coast with Sargassum following fall and winter storm events (Carr and Meylan, 1980; Witherington et al., 2006). These turtles are presumed to have been residing along a front that forms along the continental edge of the Gulf Stream off central Florida's east coast (Witherington, 2002). Recently, young green turtles have been observed residing in Sargassum habitat in the Atlantic Ocean (Witherington et al., 2012).

After an average 2.8-4.6 years ( $\mathrm{Zug}$ and Glor, 1998; Reich et al., 2007a), green turtles return to developmental habitats within neritic waters, including Florida's east coast (SCL $=20-25 \mathrm{~cm}$, Bjorndal and Bolten, 1988; Bjorndal et al., 2000a; Reich et al., 2007a). Juvenile green turtles are found in Florida's Atlantic waters along nearshore reefs (Wershoven and Wershoven, 1991; Makowski et al., 2006), in coastal lagoons (Mendonça and Ehrhart, 1982; Ehrhart et al., 2007), and to a lesser extent in shipping channels (Henwood and Ogren, 1987). The small sizes of green turtles captured in these studies indicate that turtles may be new recruits to nearshore habitats, vacating the oceanic zone to become inhabitants of coastal waters.

Juvenile green turtles are captured in the Cape Canaveral Shipping Channel throughout the year except in August and November, suggesting a lack of seasonal changes in abundance (Henwood and Ogren, 1987). However, Schmid (1995) reported that juvenile green turtles in the Cape Canaveral Shipping Channel were seasonally most abundant between November and January. Near Marquesas Keys, Fla., 
juvenile and adult green turtles forage in shallow seagrass habitats (Bresette et al., 2010). Results from these surveys suggest that size partitioning of feeding areas occurs, with large juveniles and adult turtles using deeper water foraging habitats (Bresette et al., 2010). Once reaching a certain size $(>70 \mathrm{~cm} \mathrm{SCL}$ ), large juvenile (subadult) green turtles depart coastal developmental habitats along Florida's central east coast and move to foraging grounds in the Florida Keys, Bahamas, and the Caribbean (Ehrhart et al., 2007; Bagley et al., 2008).

Traditional flipper tagging and more modern satellite telemetry techniques have indicated that the majority of adult females in Florida reside in nearshore foraging areas throughout the Florida Keys (NMFS and USFWS, 2007). Nesting females tracked from the east coast of Florida exhibited different post-nesting migrations to foraging areas near the Dry Tortugas, the southwestern coast of Florida, and across the Florida Current to the Bahamas (Witherington et al., 2006). Green turtles of various size classes tagged in coastal Florida waters have been recaptured in Cuban waters (Moncada et al., 2006) suggesting their movement likely includes Florida's Atlantic waters. Florida waters are also important migratory pathways for green turtles tagged elsewhere, including turtles from Costa Rica (Troëng et al., 2005), the Cayman Islands (Blumenthal et al., 2006), and Cuba (Moncada et al., 2006).

Green turtles have been sighted in aerial surveys along the entire east coast of Florida and are most common in nearshore waters (McClellan, 1996). In other aerial surveys, green turtles were sighted along the central east coast of Florida, west of the Gulf Stream Current (Hoffman and Fritts, 1982) and throughout the Florida Gulf Stream itself, up to $79 \mathrm{~km}$ from shore (Fritts et al., 1983).

\section{Kemp's Ridley Turtles}

Although it is believed that Kemp's ridley turtles also have an oceanic stage (Musick and Limpus, 1997; Bol- ten, 2003a), there are few such records of these turtles (Henwood and Ogren, 1987; Collard and Ogren, 1990). Manzella et al. (2001) and Witherington et al. (2012) reported on the sighting of Kemp's ridley turtles in Sargassum in the Gulf of Mexico. Stranding of small juvenile Kemp's ridleys along the southeast Florida coast also indicates their use of these waters (TEWG, 2000). Kemp's ridley turtles return to neritic benthic habitats as early as one year after hatching (Snover et al., 2007). During the juvenile stage, turtles reside within neritic foraging grounds along Florida's east coast (Henwood and Ogren, 1987).

While most Kemp's ridley turtles originate from their primary rookery in Tamaulipas, Mexico (Carr, 1963; Hildebrand, 1963, 1982), what path these turtles take to reach Florida's coastal waters is uncertain. Various scenarios for dispersal of post-hatchling Kemp's ridley turtles indicate the potential for transport through the Florida Straits and into waters along the Florida coast (Collard and Ogren, 1990; Putman et al., 2010). Sub-adult Kemp's ridleys have been captured in Cape Canaveral, Fla. (Schmid and Witzell, 1997), while juvenile Kemp's ridley turtles have been captured at Hutchinson Island, Fla. (Bresette et al., 1998), from benthic habitats consisting of sand and hard-bottom reefs. Kemp's ridley turtles have also been captured in coastal lagoons along Florida's central east coast (Ehrhart, 1983).

The greatest abundance of Kemp's ridley turtles along Florida's Atlantic waters occurs in the Port Canaveral Shipping Channel. Although turtles here range in size from $21.5-60.3 \mathrm{~cm}$ $\mathrm{SCL}$, the majority of turtles captured are juveniles (Henwood and Ogren, 1987). Along the U.S. east coast, juvenile Kemp's ridley turtles often exhibit north-south seasonal migrations (Henwood and Ogren, 1987; Keinath, 1993). Mark-recapture studies in the area indicate juvenile Kemp's ridleys likely undergo seasonal migrations, with the greatest abundance of Kemp's ridleys occurring in the winter from December to March $(\bar{x}=38.6$ $\mathrm{cm}$ SCL, range $=24.1-66.0 \mathrm{~cm} \mathrm{SCL}$; Henwood and Ogren, 1987). Kemp's ridley turtles from this area were also subsequently captured in South Carolina and Georgia in the summer and fall (Henwood and Ogren, 1987), confirming the north-south migration cycle of Kemp's ridleys.

Renaud (1995) tracked Kemp's ridley turtles along the east coast of Florida and observed nearshore coastal movements. A tracking study of juvenile Kemp's ridley turtles along the east coast of Florida indicates seasonal migrations to more northern waters in the spring (Gitschlag, 1996). Satellite tracked juvenile, sub-adult, and adult Kemp's ridley turtles from the western Gulf of Mexico displayed seasonal migrations along the west and east coasts of Florida (Renaud and Williams, 2005). In general, Kemp's ridleys inhabited waters $<20 \mathrm{~m}$ in depth but moved to deeper waters in cooler winter months followed by a return to nearshore waters in the spring (Renaud, 1995; Renaud and Williams, 2005). Some Kemp's ridley turtles were observed migrating around the southern tip of Florida and into Florida's Atlantic waters (Renaud and Williams, 2005).

Aerial surveys have provided little information on the distribution and abundance of Kemp's ridley turtles, despite their documentation throughout Florida's Atlantic waters (Epperly et al., 2002). Fritts et al. (1983) reported limited sightings of Kemp's ridley turtles $(n=2)$ during aerial surveys off the east coast of Florida, noting a higher frequency of observation along southwestern Florida.

\section{Hawksbill Turtles}

Hawksbill turtles are found throughout the Gulf of Mexico, Caribbean Sea, and in the western Atlantic. In Florida, hawksbills are relatively rare though all life stages can be found in Florida's Atlantic waters (Meylan and Redlow, 2006). Similar to other sea turtle species, the hawksbill turtle hatchling oceanic stage is associated with Sargassum (Witherington et al., 2012) for one or more years, followed 
by a neritic stage associated with hardbottom reefs, and finally a reef dwelling adult stage.

Hawksbill nesting is rare in Florida. From 1979 to 2003, only four nests per year were recorded along Florida's beaches (Meylan et al., 1995). Nesting occurs primarily from June to December with most nests documented from August to October (Meylan and Redlow, 2006). Nesting has primarily been documented along the east and southeast coast (Carr et al., 1966; Meylan and Redlow, 2006). There are no studies that examine the internesting or post-nesting movements of hawksbills along Florida's beaches, although hawksbills from Florida have been recaptured in the Bahamas and Texas (Meylan and Redlow, 2006). Stranded hawksbills have been found primarily in the Florida Keys or along the east coast of Florida and occur throughout the year with the greatest number of strandings in March and June (Meylan and Redlow, 2006).

Hawksbills are known to inhabit nearshore reefs along the central east coast of Florida (Meylan and Redlow, 2006). Juvenile hawksbill turtles are captured year-round along hardbottom reefs off the coast of Palm Beach County, Florida (Wood, 2006). In addition, juvenile hawksbills have been captured at the St. Lucie Power Plant (Bresette et al., 1998) in all months except January and February and from benthic habitats consisting of sand, and hard-bottom reefs. Wershoven (1989) captured three juvenile hawksbill turtles from hard-bottom reefs off Broward County from 1986 to 1988 , with seven recaptures of one juvenile. It may be that juvenile hawksbills inhabiting waters off the southeast coast of Florida waters forgo migration due to less severe seasonal changes in water temperature. However, further studies are needed to assess year-round abundance. Hawksbill turtles have been sighted during aerial surveys off the southwest coast of Florida, yet few sightings have occurred along the east coast (Epperly et al., 2002). Despite significant effort, little evidence is available regarding their marine distributions offshore in Florida's Atlantic waters (Meylan and Redlow, 2006).

\section{Satellite Telemetry Data}

Exploration of available satellite tracks identified an abundance of programs that tracked sea turtles throughout the northeast Atlantic Ocean. All species of sea turtle tracked were observed in Florida's Atlantic waters, though not all age classes were observed in these waters. Loggerheads composed the majority of the turtles tracked by the compiled research programs and accounted for the majority of sea turtles in tracked Florida's Atlantic waters (Table 1). Movements of adults, primarily females tagged at nesting beaches, formed the majority of loggerhead tracks in our study area. Leatherback and green turtles were the next most common species to be tracked through Florida Atlantic waters. Sub-adult loggerhead and green turtles formed the highest percentage of sea turtles crossing into Florida's Atlantic waters $(63.4 \%$ and $70.5 \%$, respectively), indicating the importance of this area for those species and age classes. The high percentage of hawksbill sub-adults observed in Florida's Atlantic waters, represents relatively few turtles, all tagged in Florida's east coast or Turks and Caicos. Relatively few adult Kemp's ridleys were tracked and those tracked in Florida's Atlantic waters were likely transients moving between summer and winter habitats.

The compilation of the data summarized here highlights data gaps in the satellite tracking of sea turtles that may use Florida's Atlantic waters. There are no available track data for adult hawksbills, yet some nesting occurs along Florida's east coast so they clearly transit the area. There is a deficiency of tracks for sub-adult and juvenile leatherbacks, adult and juvenile green turtles, as well as adult Kemp's ridleys. Because other data sources have identified these stage classes in Florida's Atlantic waters, tracking data would help address where in these waters the turtles occur.

\section{Conclusions}

Because one or more life stages of most sea turtle species are present in Florida's Atlantic waters, the importance of these waters cannot be overstated. In synthesizing the available information on sea turtle occurrence in the coastal and offshore waters east of Florida, we identified spatial and temporal concentrations of turtles, and persistent obvious gaps that exist in our understanding of their spatial and temporal distributional patterns. Despite the differences among the distributional patterns of sea turtle species in Florida's Atlantic waters, all species exhibit distinct habitat shifts and seasonal variation within study waters. Three species (loggerhead, green, and leatherback) transit coastal and offshore waters in considerable numbers when females come to nest and when hatchlings disperse away from shore. Few hawksbills and Kemp's ridleys use Florida's coastal zones for reproduction, yet they use Florida's Atlantic waters either as residents (juvenile and sub-adult hawksbills) or as migrants (Kemp's ridleys). Numerous studies focus efforts on establishing internesting and post-nesting movements of nesting female turtles, yet few have focused on the immature stages, nonnesting adults, or adult male turtles. Greater effort should be undertaken to document spatial and temporal use of the waters by juvenile turtles in nearshore and offshore habitats, adult male migratory and movement patterns, and include focus on hawksbill and Kemp's ridley activity in the Atlantic waters between Florida and the Bahamas. Such movement and habitat data are relevant to fisheries management to avoid bycatch, offshore energy development, and marine industries throughout Florida's Atlantic waters.

\section{Acknowledgments}

The authors acknowledge E. McMichael for her significant contribution to the initial development of this review and constructive comments on the manuscript. We thank the data contributors to the sea turtle tracking 
compilation for Florida's Atlantic waters and to S. Epperly for assistance with the Turtle Expert Working Group figures. We thank M. Salmon and the anonymous reviewers for constructive comments that improved this document. This work is supported by the U.S. Department of Energy, Office of Energy Efficiency and Renewable Energy through award DE-EE0000319 to the Southeast National Renewable Energy Center at Florida Atlantic University.

\section{Literature Cited}

Arendt, M. D., A. L. Segars, J. I. Byrd, J. Boynton, J. A. Schwenter, J. D. Whitaker, and L. Parker. 2012a. Migration, distribution, and diving behavior of adult male loggerhead sea turtles (Caretta caretta) following dispersal from a major breeding aggregation in the Western North Atlantic. Mar. Biol. 159:113-125.

, $\overline{\text { D. W. Ow- }}$ ens, G. Blanvillain, J. M. Quattro, and M. A. Roberts. 2012b. Seasonal distribution patterns of juvenile loggerhead sea turtles (Caretta caretta) following capture from a shipping channel in the Northwest Atlantic Ocean. Mar. Biol. 159:127-139.

J. D.

Whitaker, L. Parker, D. W. Owens, G. Blanvillain, J. M. Quattro, and M. A. Roberts. 2012c. Distributional patterns of adult male loggerhead sea turtles (Caretta caretta) in the vicinity of Cape Canaveral, Florida, USA during and after a major annual breeding aggregation. Mar. Biol. 159:101-112.

Bagley, D. A., S. A. Kubis, M. J. Bresette, and B. W. Bowen. 2008. Satellite tracking juvenile green turtles from Florida's east coast: the missing size classes found. In A. F. Rees, M. Frick, A. Panagopoulou, and K. Williams (Editors), Proceedings of the 27th Annual Workshop on Sea Turtle Biology and Conservation, p. 37. U.S. Dep. Commer., NOAA Tech. Memo. NMFS-SEFS-569.

Balon, E. K. 1986. Types of feeding in the ontogeny of fishes and the life-history model. Environ. Biol. Fishes 16(1-3):11-24.

Bell, R., and J. I. Richardson. 1978. An analysis of tag recoveries from loggerhead sea turtles (Caretta caretta) nesting on Little Cumberland Island, Georgia. Fla. Mar. Res. Publ. 33:20-24.

Bjorndal, K. A., and A. B. Bolten. 1988. Growth rates of immature green turtles, Chelonia mydas, on feeding grounds in the southern Bahamas. Copeia 1988(3):555-564.

and M. Y. Chaloupka. 2000a. Green turtle somatic growth model: evidence for density dependence. Ecol. Appl. 10(1):269-282.

, and H. R. Martins. 2000b. Somatic growth model of juvenile loggerhead sea turtles Caretta caretta: duration of pelagic stage. Mar. Ecol. Prog. Ser. 202:265-272.

, T. Dellinger, C. Delgado, and H. R. Martins. 2003. Compensatory growth in oceanic loggerhead sea turtles: re- sponse to a stochastic environment. Ecology 84:1237-1249.

Blumenthal, J. M., J. L. Solomon, C. D. Bell, T. J. Austin, G. Ebanks-Petrie, M. S. Coyne, A. C. Broderick, and B. J. Godley. 2006. Satellite tracking highlights the need for international cooperation in marine turtle management. Endanger. Species Res. 7:1-11.

Bolten, A. B. 2003a. Variation in sea turtle life history patterns: neritic vs. oceanic developmental stages. In P. L. Lutz, J. A. Musick, and J. Wyneken (Editors), The biology of sea turtles Vol. II, p. 243-257. CRC Press, Boca Raton, Fla.

2003b. Active swimmers-passive drifters: the oceanic juvenile stage of loggerheads in the Atlantic system. In A. B. Bolten and B. E. Witherington (Editors), Loggerhead sea turtles, p. 63-78. Smithson. Inst. Press, Wash., D.C.

K. A. Bjorndal, H. R. Martins, T. Dellinger, M. J. Biscoito, S. E. Encalada, B. W. Bowen. 1998. Transatlantic developmental migrations of loggerhead sea turtles demonstrated by mtDNA sequence analysis. Ecol. Appl. 8(1):1-7.

Bowen, B. W., A. L. Bass, L. Soares, and R. J. Toonen. 2005. Conservation implications of complex population structure: lessons from the loggerhead turtle (Caretta caretta). Mol. Ecol. 14:2389-2402.

Bresette, M., J. Gorham, and B. Peery. 1998. Site fidelity and size frequencies of juvenile green turtles (Chelonia mydas) utilizing near shore reefs in St. Lucie County, Florida. Mar. Turtle Newsl. 82:5-7.

B. E. Witherington, R. M. Herren, D. A. Bagley, J. C. Gorham, S. L. Traxler, C. K. Crady, and R. Hardy. 2010. Size-class partitioning and herding in a foraging group of green turtles Chelonia mydas. Endang. Species Res. 9:105-116.

Caldwell, D. K., and A. Carr. 1957. Status of the sea turtle fishery in Florida. In Trans. $22^{\text {nd }} \mathrm{N}$. Am. Wildl. Conf., p. 457-463. Wildl. Manage. Inst., Wash., D.C.

, and L. H. Ogren. 1959. The Atlantic loggerhead sea turtles, Caretta caretta caretta (L.) in America. 1. Nesting and migration of the Atlantic loggerhead turtles. Bull. Fla. State Mus. Biol. Sci. 4(10):295-308.

Carr, A. 1963. Panspecific reproductive convergence in Lepidochelys kempii. Ergebn. Biol. 26:298-303

1986. Rips, FADS, and little loggerheads. Bioscience 36:92-101.

1987. New perspectives on the pelagic stage of sea turtle development. Conserv. Biol. 1:103-121.

and L. Ogren. 1960. The ecology and migrations of sea turtles. 4: The green turtle in the Caribbean Sea. Bull. Am. Mus. Nat. Hist. 121:1-48.

H. Hirth, and L. Ogren. 1966. Ecology and migrations of sea turtles. 6: The hawksbill turtle in the Caribbean Sea. Am. Mus. Novit. 2248:1-29.

L. Ogren, and C. McVea. 1980. Apparent hibernation by the Atlantic loggerhead turtles Caretta caretta off Cape Canaveral, Florida. Biol. Conserv. 19(1980-81):7-14. and A. B. Meylan. 1980. Evidence of passive migration of green turtle hatchlings in Sargassum. Copeia 1980(2):366-368.
Casale, P., G. Abbate, D. Freggi, N. Conte, M. Oliverio, and R. Argano. 2008. Foraging ecology of loggerhead sea turtles Caretta caretta in the central Mediterranean Sea: evidence for a relaxed life history model. Mar. Ecol. Prog. Ser. 372:265-276.

Ceriani, S. A., J. D. Roth, D. R. Evans, J. F. Weishampel, and L. M. Ehrhart. 2012. Inferring foraging areas of nesting loggerhead turtles using satellite telemetry and stable isotopes. PLoS ONE 7(9):e45335. doi:10.1371/ journal.pone.0045335.

Collard, S. B., and L. H. Ogren. 1990. Dispersal scenarios for post-hatchling sea turtles. Bull. Mar. Sci. 47(1):233-243.

Coston-Clements, L., L. R. Settle, D. E. Hoss and F. A. Cross. 1991. Utilization of the Sar gassum habitat by marine invertebrates and vertebrates: a review. U.S. Dep. Commer. NOAA Tech. Memo. NMFS-SEFSC-296, 32 p.

Crawford, S. S., and E. K. Balon. 1994. Alternative life histories of the genus Lucania: 3 : an ecomorphological explanation of altricia (L. parva) and precocial (L. goodie) species. Environ. Biol. Fishes 41:369-402.

Dodd, C. K., Jr. 1988. Synopsis of the biological data on the loggerhead sea turtle Caretta caretta (Linnaeus 1758). U.S. Fish Wildl. Serv., Biol. Rep. 88(14), 110 p.

and R. Byles. 2003. Post-nesting movements and behavior of loggerhead sea turtles (Caretta caretta) departing from east-central Florida nesting beaches. Chelonian Conserv. Biol. 4(3):530-536.

Eckert, S. A. 1998. Perspectives on the use of satellite telemetry and electronic technologies for the study of marine turtles, with reference to the first year long tracking of leatherback sea turtles. In S. P. Epperly, and J. Braun (Editors), Proceedings of the Seventeenth Annual Symposium on Sea Turtle Biology and Conservation, p. 44-46. U.S. Dep. Commer. NOAA Tech. Memo. NMFS-SEFSC-415. 2002. Distribution of juvenile leatherback sea turtle Dermochelys coriacea sightings. Mar. Ecol. Prog. Ser. 230:289-293. D. Bagley, S. Kubis, L. Ehrhart, C. Johson, K. Stewart, and D. DeFreese. 2006. Internesting and postnesting movements and foraging habitats of leatherback sea turtles (Dermochelys coriacea) nesting in Florida. Chelonian Conserv. Biol. 5:239-248.

Ehrhart, L. M. 1983. Marine turtles of the Indian River Lagoon System. Fla. Sci. 46:337-346. D. A. Bagely, and W. E. Redfoot. 2003.

Loggerhead sea turtles in the Atlantic Ocean: geographic distribution, abundance, and population status. In A. B. Bolten and B. E. Witherington (Editors), Loggerhead sea turtles, $\mathrm{p}$. 157-174. Smithson. Inst., Wash., D.C.

W. E. Redfoot, and D. A. Bagley. 2007. Marine turtles of the central region of the Indian River Lagoon system, Florida. Fla. Sci. 70:415-434.

Epperly, S. P. J. Braun, and A. J. Chester. 1995. Aerial surveys for sea turtles in North Carolina inshore waters. Fish. Bull. 93:254-261. L. Avens, L. Garrison, T. Henwood W. Hoggard, J. Mitchell, J. Nance, J. Poffenberger, C. Sasso, E. Scott-Denton, and C. Yeung. 2002. Analysis of sea turtle bycatch in the commercial shrimp fisheries of southeast U.S. waters and the Gulf of Mexico. U.S Dep. Commer., NOAA Tech. Memo. NMFSSEFSC-490, $88 \mathrm{p}$ 
Fishelson L., L. W. Montgomery, and A. H. Myrberg, Jr. 1987. Biology of surgeonfish Acanthurus nigrofuscus with emphasis on changeover in diet and annual gonadal cycles. Mar. Ecol. Prog. Ser. 39:37-47.

Foley, A. M., B. A. Schroeder, and S. L. MacPherson. 2008. Post-nesting migrations and resident areas of Florida loggerhead turtles (Caretta caretta). In H. Kalb, A. S. Rohde, K. Gayheart, and K. Shanker (Editors), Proceedings of the 25th Annual Workshop on Sea Turtle Biology and Conservation, p. 75-76. U.S. Dep. Commer. NOAA Tech. Memo. NMFS-SEFS-SEFSC 582.

Fritts, T. H., W. Hoffman, and M. A. McGehee. 1983. The distribution and abundance of marine turtles in the Gulf of Mexico and nearby Atlantic waters. J. Herpetol. 17:327-344.

Girard, C., A. D. Tucker, and B. Calmettes. 2009. Post-nesting migrations of loggerhead sea turtles in the Gulf of Mexico: dispersal in highly dynamic conditions. Mar. Biol. 156:1827-1839.

Gitschlag, G. R. 1996. Migration and diving behavior of Kemp's ridley (Garman) sea turtles along the U.S. southeastern Atlantic coast. J. Exp. Mar. Biol. Ecol. 205:115-135.

Godley, B. J., J. M. Blumenthal, A. C. Broderick, M. S. Coyne, M. H. Godfrey, L. A. Hawkes, and M. J. Witt. 2008. Satellite tracking of sea turtles: where have we been and where do we go next? Endang. Species Res. 4:3-22.

Goodman, M. A., J. Braun-McNeill, E. Davenport, and A. A. Hohn. 2007. Protected species aerial survey data collection and analysis in waters underlying the R-5306A airspace. Final rep. U.S. Marine Corps, MCAS Cherry Point. U.S. Dep. Commer., NOAA Tech. Memo. NMFS-SEFSC-551, $25 \mathrm{p}$

Hatase, H., K. Sato, M. Yamaguchi, K. Takahashi, and K. Tsukamoto. 2006. Individual variation in feeding habitat use by adult female green sea turtles (Chelonia mydas): are they obligately neritic herbivores? Oecologia 149(1):52-64

Hawkes, L. A., A. C. Broderick, M. S. Coyne, M. H. Godfrey, and B. J. Godley. 2007. Only some like it hot-quantifying the environmental niche of the loggerhead sea turtles. Divers. Distrib. 13(4):447-457.

M. J. Witt, A. C. Broderick, J. W. Coker, M. S. Coyne, M. Dodd, M. G. Frick, M. H. Godfrey, D. B. Griffin, S. R. Murphy, T. M. Murphy, K. L. Williams, and B. J. Godley. 2011. Home on the range: spatial ecology of loggerhead turtles in Atlantic waters on the USA. Divers. Distrib. 17(4):624-640.

Henwood, T. A.. 1987. Movements and seasonal changes in loggerhead turtles Caretta caretta aggregations in the vicinity of Cape Canaveral, Florida (1978-84). Biol. Conserv. 40:191-202.

and L. H. Ogren 1987. Distribution and migrations of immature Kemp's ridley turtle (Lepidochelys kempii) and green turtles (Chelonia mydas) off Florida, Georgia, and South Carolina. N.E. Gulf Sci. 9:153-159.

and S. P. Epperly. 1999. Aerial surveys in foraging habitats. In K. L. Eckert, K. A. Bjorndal, F. A. Abreu-Grobois, and M. Donnelly (Editors), Research and management techniques for the conservation of sea turtles, p. 65-66. IUCN/SSC Mar. Turtle Spec. Group Publ. 4.

Hildebrand, H. H. 1963. Hallazgo del area de anidacion de la tortuga marina 'lora', Lepido- chelys kempii (Garman), en la costa occidental del Golfo de Mexico. Ciencia, Mex., 22 (1963):105-112.

1982. A historical review of the status of sea turtle populations in the western Gulf of Mexico. In K. A. Bjorndal (Editor), Biology and conservation of sea turtles (rev. ed.), p. 447-453. Smithson. Inst. Press, Wash., D.C.

Hoffman, W., and T. H. Fritts. 1982. Sea turtles distribution along the boundary of the Gulf Stream Current off eastern Florida. Herpetologica 38(3):405-409.

Hughes, G. R., P. Luschi, R. Mencacci, and F. Papi. 1998. The 7000-km journey of a leatherback turtle tracked by satellite. J. Exp. Mar. Biol. Ecol. 229(2):209-217.

James, M. C., C. A. Ottensmeyer, and R. A. Myers. 2005. Identification of high-use habitat and threats to leatherback sea turtles in northern waters: new directions for conservation. Ecol. Lett. 8:195-201.

Keinath, J. A. 1993. Movements and behavior of wild and head started sea turtles. Ph.D. dissert., Va. Inst. Mar. Sci., Coll. William \& Mary, Gloucester Pt., Va., 206 p.

Kitowski, I. 2003. Age-related differences in foraging behavior of Montagu's harrier Circus pygargus males in south-east Poland. Acta Ethologica 6(1):35-38.

Lind, A. J., and H. H. Welsh 1994. Ontogenetic changes in foraging behaviour and habitat use by the Oregon garter snake, Thamnophis atratus hydrophilus. Anim. Behav. 48(6):1261-1273.

Lutcavage, M., and J. Musick. 1985. Aspects of the biology of sea turtles in Virginia. Copeia 1985(2):449-456.

Makowski, C., J. A. Seminoff, and M. Salmon. 2006. Home range and movements of juvenile Atlantic green turtles (Chelonia mydas L.) on shallow reef habitats in Palm Beach, Florida, USA. Mar. Biol. 148(5):1167-1179.

Mansfield, K. L. 2006. Sources of mortality, movements and behavior of sea turtles in Virginia. Ph.D. dissert., Va. Inst. Mar. Sci., Coll. William \& Mary, Gloucester Pt., Va., 343 p. V. S. Saba, J. A. Keinath, and J. A Musick. 2009. Satellite tracking reveals a dichotomy in migration strategies among juvenile loggerhead turtles in the Northwest Atlantic. Mar. Biol. 156(12):2555-2570.

Manzella, S., J. Williams, B. Schroeder, and W. Teas. 2001. Juvenile head-started Kemp's Ridleys found in floating grass mats. Mar. Turtle Newsl. 52:5-6.

McClellan, D. B. 1996. Aerial surveys for sea turtles, marine mammals, and vessel activity along the southeast coast of Florida, 1992-1996. U.S. Dep. Commer., NOAA Tech Memo NMFS-SEFSC-390, $42 \mathrm{p}$

McClellan, C. M., and A. J. Read. 2007. Complexity and variation in loggerhead sea turtle life history. Biol. Lett. 3:592-594.

Mendonça, M. T., and L. M. Ehrhart. 1982. Activity, population size and structure of immature Chelonia mydas and Caretta caretta in Mosquito Lagoon, Florida. Copeia 1982(1):161-167.

Meylan, A. 1995. Sea turtle migrations - evidence from tag returns. In K. A. Eckert (Editor), Biology and conservation of sea turtles, p. 91-100. Smithson. Inst. Press, Wash., D.C. and A. Redlow. 2006. Eretmochelys imbricata-hawksbill turtle. In P. A. Meylan
(Editor), Biology and conservation of Florida turtles, p.105-127 Chelonian Res. Monogr. 3.

, K. A. Bjorndal, and B. J. Turner. 1983. Sea turtles nesting at Melbourne Beach, Florida, II. Post-nesting movements of Caretta caretta. Biol. Conserv. 26:79-90.

, B. E. Witherington, B. Brost, R. Rivero, and P. S. Kubilis. 2006. Sea turtle nesting in Florida, USA: assessments of abundance and trends for regionally significant populations of Caretta, Chelonia, and Dermochelys. In M. Frick, A. Panagopoulou, A. F. Rees, and $\mathrm{K}$. Williams (Editors), Book of abstracts. Twenty-sixth Annual Symposium on Sea Turtle Biology and Conservation, p. 306-307. Int. Sea Turtle Soc., Athens, Greece.

Miller, J. D. 1997. Reproduction in sea turtles. In P. L. Lutz, and J. A. Musick (Editors), The biology of sea turtles, p. 51-81. CRC Press, Boca Raton, Fla.

Moncada, F., F. A. Abreu-Grobois, A. MuhliaMelo, C. Bell, S. Tröeng, K. A. Bjorndal, A. B. Bolten, A. B. Meylan, J. Zurita, G. Espinosa, G. Nodarse, R. Márquez-Millán, A. Foley, and L. Ehrhart. 2006. Movement patterns of green turtles (Chelonia mydas) in Cuba and adjacent Caribbean waters inferred from flipper tag recaptures. J. Herpetol. 40(1):22-34.

Monzón-Argüello, C., C. Rico, C. Carreras, P. Calabuig, A. Marco, and L. F. López-Jurado. 2009. Variation in spatial distribution of juvenile loggerhead turtles in the eastern Atlantic and western Mediterranean Sea. J. Exp. Mar. Biol. Ecol. 373(2):79-86.

Mortimer, J. A., and K. M. Porter. 1989. Reproductive homing and internesting behavior of the green turtle (Chelonia mydas) at Ascension Island, South Atlantic Ocean. Copeia 1989(4):962-977.

Mrosovsky, N. 1987. Leatherback turtle off scale. Nature 327:319-320.

Musick, J. A., and C. J. Limpus 1997. Habitat utilization and migration in juvenile sea turtles. In P. L. Lutz, and J. A. Musick (Editors), The biology of sea turtles, p.137-163. CRC Press, Boca Raton, Fla.

National Marine Fisheries Service and U.S. Fish and Wildlife Service. 2007. Green sea turtle (Chelonia mydas) 5-year review: summary and evaluation. NMFS, Silver Spring, Md and USFWS SE Reg., Jacksonville Ecol Serv. Field Off., Jacksonville, Fla., 102 p.

Ogren, L., and C. McVea. 1995. Apparent hibernation by sea turtles in North American waters. In K. A. Bjorndal (Editor), Biology and conservation of sea turtles, p. 127-132. Smithson. Inst. Press, Wash., D.C.

Page, B., J. McKenzie, and S. D. Goldsworthy. 2005. Dietary resource partitioning amons sympatric New Zealand and Australian fur seals. Mar. Ecol. Prog. Ser. 293:283-302.

Phillips, K. 2011. Beyond the beach: Population trends and foraging site selection of a Florida loggerhead nesting assemblage. Open Access Theses. Paper 245. http://scholarlyrepository. miami.edu/oa theses/245.

Plotkin, P. T., and J. R. Spotila. 2002. Post-nesting migrations of loggerhead turtles Caretto caretta from Georgia, USA: conservation implications for a genetically distinct subpopulation. Oryx 36:396-399.

Polovina, J., I. Uchida, G. Balazs, E. A. Howell, D. Parker, and P. Dutton. 2006. The Kuroshio Extension Bifurcation Region: a pelagic hotspot for juvenile loggerhead sea turtles. 
Deep-Sea Res. Pt. II: Topical Stud. Oceanogr. 53(3):326-339

Price, T. D., and P. R. Grant. 1984. Life history traits and natural selection for small body size in a population of Darwin's finches. Evolution 38:483-494.

Putman, N. F., T. J. Shay, and K. J. Lohmann. 2010. Is the geographic distribution of nesting in the Kemp's ridley turtle shaped by the migratory needs of offspring? Integr. Comp. Biol. 50(3):305-314

Reich, K. J., K. A. Bjorndal, and A. B. Bolten. 2007a. The 'lost years' of green turtles: using stable isotopes to study cryptic lifestages. Biol. Lett. 2(6):712-714.

Reich, K. J., K. A. Bjorndal, A. B. Bolten, and B. E. Witherington. 2007b. Do some loggerheads nesting in Florida have an oceanic foraging strategy? An assessment based on stable isotopes. In Proceedings of the Twenty-fourth Annual Symposium on Sea Turtle Biology and Conservation. p. 32. U.S. Dep. Commer., NOAA Tech. Memo. NMFS-SEFSC-567.

Renaud, M. L. 1995. Movements and submergence patterns of Kemp's ridley turtles (Lepidochelys kempii). J. Herpetol. 29:370-374.

and J. A. Williams. 2005. Kemp's ridley sea turtle movements and migrations. Chelonian Conserv. Biol. 4(4):808-816.

Schmid, J. R. 1995. Marine turtle populations on the east-central coast of Florida: results of tagging studies at Cape Canaveral, Florida, 1986-1991. Fish. Bull. 93:139-151. and W. N. Witzell. 1997. Age and growth of wild Kemp's ridley turtles (Lepidochelys kempi): cumulative results of tagging studies in Florida. Chelonian Conserv. Biol. 2(4):532-537.

Schroeder, B. A., and N. B. Thompson. 1987. Distribution of the loggerhead turtle, Caretta caretta, and the leatherback turtle, Dermochelys coriacea, in the Cape Canaveral, Florida area: results of aerial surveys. In W. N. Witzell (Editor), Ecology of east Florida sea turtles, p. 45-54. U.S. Dep. Commer., NOAA Tech. Rep. NMFS-SEFSC-53.

A. M. Foley, B. E. Witherington, and A. E. Mosier. 1998. Ecology of marine turtles in Florida Bay: population structure, distribution, and occurrence of FP. In S. P. Epperly and J. Braun (Editors), Proceedings of the Seventeenth Annual Symposium on Sea Turtle Biology and Conservation, p. 281-283. U.S. Dep. Commer., NOAA Tech. Memo. NMFS-SEFSC-41.

Snover, M. L. 2008. Ontogenetic habitat shifts in marine organisms: influencing factors and the impact of climate variability. Bull. Mar. Sci. 83(1):53-67.

A. A. Hohn, L. R. Goshe, and G. H.

Balazs. 2007. Age and growth in Kemp's ridley sea turtles: evidence from mark recapture and skeletochronology. In P. Plotkin (Editor), Synopsis of the biology and conservation of the ridley sea turtle, p. 89-105. Smithson. Inst. Press, Wash., D.C

A. A. Hohn, L. B. Crowder, and S. A. Macko. 2010. Combining stable isotopes and skeletal growth marks to detect habitat shifts in juvenile loggerhead sea turtles Caretta caretta. Endanger. Species Res. 13(1):25-31.

Stewart, K., and C. Johnson. 2006. Dermochelys coriacea -leatherback sea turtle. In P. A. Meylan (Editor), Biology and conservation of Florida turtles, p. 144-157 Chelonian Res. Monogr. 3.

, M. Sims, A. Meylan, B. Witherington, B. Brost, and L. B. Crowder. 2011. Leatherback nests increasing significantly in Florida, USA; trends assessed over 30 years using multilevel modeling. Ecol. Appl. 21:263-273.

Stoneburner, D. L. 1982. Satellite telemetry of loggerhead sea turtle movement in the Georgia Bight. Copeia 1982(2):403-408.

Thompson, N. B., E. S. Denton, D. B. Koi, A. Martinez, and K. Mullin. 1991. Turtles in the Gulf of Mexico: pelagic distributions and commercial shrimp trawling. U.S. Dep. Commer., NOAA Tech. Memo. NMFSSEFSC-286, $12 \mathrm{p}$

Troëng, S., D. R. Evans, E. Harrison, and C. J. Lagueux. 2005. Migration of green turtles Chelonia mydas from Tortuguero, Costa Rica. Mar. Biol. 148:435-447.

TEWG (Turtle Expert Working Group). 2000. Assessment for the Kemp's ridley and loggerhead sea turtle populations in the western North Atlantic. U.S. Dep. Commer., NOAA Tech. Memo. NMFS-SEFSC-444, 115

2007. An assessment of the leatherback turtle population in the Atlantic Ocean. U.S. Dep. Commer., NOAA Tech. Memo. NMFS-SEFSC-555, $116 \mathrm{p}$

2009. An assessment of the loggerhead turtle population in the western North Atlantic. U.S. Dep. Commer., NOAA Tech. Memo. NMFS-SEFSC-575, $131 \mathrm{p}$

Wainwright, P. C., and B. A. Richard. 1995. Predicting patterns of prey use from morphology with fishes. Environ. Biol. Fish. 44:97-113.

Wershoven, R. 1989. Assessment of utilization of sleeping habitat by juvenile turtles off Broward County, Florida. In L. Ogren, F. Berry, K. Bjorndal, H. Kumpf, R. Mast, G. Medina, H. Reichart, and R. Witham (Editors), Proceedings of the Second Western Atlantic Turtle Symposium, p. 347-348. U.S. Dep. Commer., NOAA Tech. Memo. NMFS-SEFC-226.

Wershoven, J. L., and R. W. Wershoven. 1991. Juvenile green turtles in their nearshore habitat of Broward County, Florida: a five year review. In M. Salmon, and J. Wyneken (Editors), Proceedings of the Eleventh Annual Workshop on Sea Turtle Biology and Con- servation, p. 121-123. U.S. Dep. Commer. NOAA Tech. Memo. NMFS-SEFSC-302.

Williams, K. L., and M. G. Frick. 2008. Tag returns from loggerhead turtles from Wassaw Island, GA. Southeast. Nat. 7(1):165-172.

Witham, R. 1980.The "lost year" question in young sea turtles. Am. Zool. 20(3):525-530.

Witherington, B. E. 2002. Ecology of neonate loggerhead turtles inhabiting lines of downwelling near a Gulf Stream front. Mar. Biol. 140:843-853.

M. Bresette, and R. Herren. 2006. Chelonia mydas - green turtle. In P. A. Meylan (Editor), Biology and conservation of Florida turtles. Chelonian Res. Monogr. 3:90-104.

S. Hirama, and R. Hardy. 2012. Young sea turtles of the pelagic Sargassum-dominated drift community: habitat use, population density, and threats. Mar. Ecol. Prog. Ser. 463:1-22.

Witzell, W. N. 1998. Long-term tag returns from juvenile Kemp's ridleys. Mar. Turtle Newsl. 79:20

1999. Distribution and relative abundance of sea turtles caught incidentally by the U.S. pelagic longline fleet in the western North Atlantic Ocean, 1992-1995. Fish. Bull. 97(1):200-211.

2002. Immature Atlantic loggerhead turtles (Caretta caretta): suggested changes to the life history model. Herpetol. Rev. 33(4):266-269.

and J. Cramer. 1995. Estimates of sea turtle by-catch by the U.S. pelagic longline fleet in the western North Atlantic Ocean. U.S. Dep. Commer., NOAA Tech. Memo. NMFS-SEFSC-359, $14 \mathrm{p}$.

and T. Azarovitz. 1996. Relative abundance and thermal and geographic distribution of sea turtles off the US Atlantic coast based on aerial surveys (1963-1969). U.S Dep. Commer., NOAA Tech. Memo. NMFSSEFSC-381, $10 \mathrm{p}$

A. L. Bass, M. J. Bresette, D. A. Singewald, and J. C. Gorham. 2002. Origin of immature loggerhead sea turtles (Caretta caretta) at Hutchinson Island, Florida: evidence from mtDNA markers. Fish. Bull. 100(3):624-631

Wood, L. D. 2006. A preliminary assessment of hawksbill turtles (Eretmochelys imbricata) in Palm Beach county waters. In M. A. Frick, A. Panagopoulou, A. Rees, and K. Williams (Editors), Book of abstracts. Twenty-sixth Annual Symposium on Sea Turtle Biology and Conservation, p. 336. Int. Sea Turtle Soc., Athens, Greece.

Zug, G. R., and R. E. Glor. 1998. Estimates of age and growth in a population of green sea turtles (Chelonia mydas) from the Indian River lagoon system, Florida: A skeletochronological analysis. Can. J. Zool. 76(8):1497-1506. 